\title{
The Relationship between Locus of Control, Test Anxiety, and Religious Orientation among Iranian EFL Students
}

\author{
Mina Rastegar, Nahid Heidari \\ Foreign Language Department, Shahid Bahonar University, Kerman, Iran \\ Email: rastegar@uk.ac.ir
}

Received October $31^{\text {st }}, 2011$; revised December $26^{\text {th }}, 2011$; accepted January $4^{\text {th }}, 2012$

\begin{abstract}
The present study was designed to investigate the relationship between locus of control (LOC), religious orientation (RO) and test anxiety (TA) among Iranian EFL learners. Furthermore, it scrutinized the role of gender on these variables. To achieve such goals, 100 Iranian EFL students (57 females, 43 males) studying English at Shahid Bahonar University of Kerman participated in the study. These students were randomly selected from among junior and senior students majoring in English Translation and English Literature. In order to obtain the required data, three questionnaires were utilized: Rotters's (1966) locus of control scale (LOCS) to measure participants' level of LOC, Sarason's (1975) test anxiety scale (TAS) to measure participants' TA, and Allport and Ross's (1967) Religious Orientation Scale (ROS) to determine participants' intrinsic or extrinsic religious orientation. For analysis of data, the Pearson Product Moment Correlation and T-test were used. The results revealed that there was a significant negative relationship between ILOC and TA and a significant positive relationship between ELOC and TA. Furthermore, there was a significant positive relationship between ILOC and IRO and a significant positive relationship between ELOC and ERO. Also, there was a significant negative relationship between ILOC and TA, and a significant positive relationship between ELOC and TA. Finally, there were not any significant differences among males and females regarding ILOC, ELOC, TA, IRO, and ERO.
\end{abstract}

Keywords: Locus of Control (LOC); Test Anxiety (TA); Religious Orientation (RO); Gender

\section{Introduction}

It is undoubtedly true that learners bring many individual characteristics to the learning process which will affect both the way in which they learn and the outcomes of that process. Locus of control (LOC), test anxiety (TA), and religious orientation (RO) are among these characteristics, and their relationship will be investigated in this study.

The question of whether or not we control our own fate has been the topic of debate for centuries. Religion and literature have both had a long history of trying to discern what forces shape our future. As early as the Ancient Greek times, philosophers and writers focused on the idea of fate and free will. While some find the idea of having a greater power drive our lives comforting, others find it frightening. Further, there are those who rely on the idea of not being in control of their lives to justify their actions or explain their misfortunes. Because of the mixed emotions surrounding fate, destiny, and free choice, numerous works from the ancient times until now focus on locus of control (LOC).

The concept of locus of control was first introduced by Rotter (1966). LOC (Rotter, 1966) is conceptualized on a dynamic bipolar continuum spanning from internal to external. Internal locus of control (ILOC) is characterized by the belief that consequences are a result of one's own behavior. In other words, individuals who believe that their successes or failures result from their own behaviors possess an internal locus of control. On the other hand, external locus of control (ELOC) is characterized by the belief that consequences are a result of fate, luck, or powerful others. In other words, individuals who attribute their successes or failures to something incongruent with their own behaviors possess an external locus of control.

The second variable of this study is test anxiety. Test anxiety refers to worry, apprehension, palpitation, increase in pulse rate and other physiologic symptoms during the exam. (Abolghasemi, Asadi, Moghadam, Najarian, \& Shokrkon, 1996; Vitasari, Nubli, Othman, Herrawan, \& Sinnadurai, 2010). TA negatively affects academic performance. According to Sarason and Sarason (1990), High-test-anxious students express concern about the consequences of not performing at a satisfactory level on major exams and embarrassment at probable failure. Also, test-anxious college students, relative to their low-test-anxious counterparts, report suffering from poor mental health and psychosomatic symptoms (Depreeuw \& DeNeve, 1992). Spielberger (1972) reported that students who are high in test anxiety tend to have poor study habits and test taking skills.

The third variable of this study is religious orientation (RO). Religious orientation has been defined as the "extent to which a person lives out his/her religious beliefs" (Allport \& Ross, 1967: p. 433). Allport and Ross (1967) originally conceptualized religious orientation as a single construct varying along a continuum between intrinsic and extrinsic belief systems. More extrinsically oriented individuals "use religion to their own needs" (Allport \& Ross, 1967: p. 434), and "Persons with intrinsic religious orientation find their master motive in religion" (Allport \& Ross, 1967: p. 434).

The relationship among I-E LOC, TA, and I-E RO, will be investigated in this study. Furthermore, this study scrutinizes the role of gender on these variables. 


\section{Literature Review}

\section{Relationship between LOC and TA}

In the literature, external LOC is typically positively correlated with TA (Archer, 1979; Beekman et al., 2000; Berrenberg, 1987; Gabbard, Howard, \& Tageson, 1986; Moore, 2006; Watson, 1967). Similar findings occurred among college students (Watson, 1967), older adults (Beekman et al., 2000), adolescents, army recruits, alcoholics, and emotionally disturbed children (see Archer, 1979 review).

Furthermore, Berrenberg's (1987) study of undergraduates relating a scale of exaggerated internal LOC to test anxiety found a negative correlation between internal LOC and test anxiety. However, in another investigation, the relationship between locus of control, procrastination and anxiety revealed that internals experienced higher academic procrastination and test anxiety than externals (Carden, Bryant, \& Moss, 2004).

\section{Relationship between LOC and RO}

The first substantial investigation of the relationship between religious orientation and locus of control was conducted by Strickland and Shaffer (1971). Strickland and Shaffer (1971) found that locus of control, measured as extent of externality, and internal religious orientation were negatively correlated ( $\mathrm{r}$ $=-.30$ ). Moreover, research indicated intrinsic religiousness is positively related to internal LOC (Kahoe, 1974; Strickland \& Shaffer, 1971, Sturgeon \& Hamley, 1979).

However, in a study by McIntosh, Kojetin, and Spilka (1985), involving students enrolled in an introductory psychology course at the University of Denver, no significant correlation was found between E-I LOC and religious orientation. It is possible that this result may have been due to the use of an instrument specifically designed for people with some form of religious involvement, with a sample of subjects not representative of the latter.

\section{Relationship between RO and TA}

Typically, intrinsic religiousness is negatively related to test anxiety (Baker \& Gorsuch, 1982; Bergin, Masters, \& Richards, 1987; Koenig, Moberg, \& Kvale, 1988; Maltby, Lewis, \& Day 1999; Sturgeon \& Hamley, 1979). Furthermore, in most studies, extrinsic religiousness is positively related to test anxiety (Baker \& Gorsuch, 1982; Bergin et al., 1987; Watson et al., 2002).

However, some non-significant results for the relation between intrinsic religiousness and test anxiety have also been found in samples of American, English, and Iranian college students (Maltby \& Day, 2000; Watson et al., 2002).

\section{LOC, TA, RO, and Gender}

Results on gender differences in locus of control have varied. Nowicki and Strickland (1973) found a negative relationship between the locus of control and achievement of children in grades 3 - 12. As achievement scores went up, external scores went down, and this was mostly found in males. McLaughlin and Saccuzzo (1997) found that gender effects were apparent with females showing a slight but significantly greater internal locus of control. Young and Shorr (1986) found that females tend to attribute both success and failure outcomes to internal causes significantly more often than males.
Regarding the relationship between test anxiety and gender, (Hembree, 1988; Lashkaripour, Bakhshani, \& Soleymani, 2007; Mousavi, Haghshenas, \& Alishahi, 2008; Putwain, 2007; Zeidner, 1998) investigated the relationship between test anxiety, academic achievement, and gender. The results of this study showed that, test anxiety occurred in girls more than boys and this difference was significant. On the other hand, there are some contradictory results regarding gender and TA. Fan, Chen, and Matsumoto (1997), Hyde, Fennema, and Lamon (1990), Pajares and Graham (1999) explored the relationship between TA and gender and reported that the differences among females and males regarding TA were non-significant and slight.

Regarding RO and gender, it is commonly accepted that women are more religious than men. Numerous surveys going back at least a century have repeatedly found this to be the case (Beit-Hallahmi \& Argyle, 1997; Brown, 1987; Francis, 1997; Paloutzian, 1996; Walter \& Davie, 1998). Batson, Schoenrade, and Ventis's overview (1993), on predominantly Christian samples, reported higher levels of attendance and Bible study among women than among men. Beit-Hallahmi and Argyle (1997) concluded that there were higher levels of religious involvement, prayer, experience and overall religiosity among women compared to men, and suggested that these gender differences may be a reflection of greater opportunity among women for religious activity, or perhaps of differences in personality and socialization.

\section{Research Questions}

This study aims at seeking answers to the following major and minor research questions.

\section{Major Research Questions}

1) Is there any relationship between internal-external locus of control and test anxiety among Iranian EFL learners?

2) Is there any relationship between internal-external locus of control and intrinsic-extrinsic religious orientation among Iranian EFL learners?

3) Is there any relationship between intrinsic-extrinsic religious orientation and test anxiety among Iranian EFL learners?

\section{Minor Research Question}

4) Are there any differences among males and females considering internal locus of control, external locus of control, test anxiety, intrinsic religious orientation, and extrinsic religious orientation?

\section{Methodology}

\section{Participants}

One hundred Iranian EFL students studying at the department of foreign languages of Shahid Bahonar University of Kerman took part in this study. These students, including both males and females, were randomly selected from junior and senior students majoring in English Translation and English Literature. Among the sample population, there were fifty seven females $(57 \%)$ and forty three males $(43 \%)$.

\section{Instruments}

In order to obtain the required data on the variables locus of 
control, test anxiety, and religious orientation, three questionnaires were utilized:

1) Locus of Control Scale (Rotter, 1966);

2) Test Anxiety Scale (Sarason, 1975);

3) Religious Orientation Scale (Allport \& Ross, 1967).

\section{Locus of Control Scale (Rotter, 1966)}

Rotter's (1966) LOC scale was used to measure an individual's internal-external orientation. The scale is referred to as the I-E scale and provides a measure of individual differences in a generalized belief for internal versus external control of reinforcement. It is a two-point scale and participants are supposed to select choice (a) or (b) in each part. The scale consists of 29 items. Of the 29 items, 23 related to internal-external expectancies, and 6 are filler items intended to disguise the purpose of the test. Students' answers can range from 1 to 23 , and the scores obtained from this scale were divided into two groups by the researcher in order to make the analysis of the data easier. Scores from 1 - 10 indicated ILOC and scores above 10 indicated ELOC. Item and factor analyses indicated high internal consistency, test-retest reliability was satisfactory, and the test correlated satisfactorily with other method of assessing the same variable (Rotter, 1966).

\section{The Test Anxiety Scale (Sarason, 1975)}

Sarason's (1975) test anxiety scale (TAS) was used as the research tool to determine the students' degree of test anxiety. Sarason's (1975) TAS is a Likert scale with 37 items which reflect the multi-componential aspects of test anxiety (Zeinder, 1998). The items are based on the evidence that test anxiety is composed of test-relevant and test-irrelevant thinking. Responses range from 1 (completely disagree) to 5 (completely agree). For each item, the highest degree of anxiety receives five points and the lowest, one point. Students' scores can range from 37 to 185 , the greater the number, the stronger the degree of test anxiety. The TAS is a reliable instrument in identifying students' anxiety experience in language learning. The internal consistency measure of TAS showed an alpha coefficient of 90 (Aydin, Karakuza, \& Elkilik, 2009).

\section{Religious Orientation Scale (Allport \& Ross, 1967)}

Allport and Ross's (1967) Religious Orientation Scale (ROS) was used to determine the participants' I-E RO. The scale con- sists of 20 items divided into two subscales, intrinsic and extrinsic. The intrinsic sub-scale has 9 items, while the extrinsic sub-scale has 11 items. The questions were answered using a 5 point Likert scale and responses range from 1 (strongly disagree) to 5 ( strongly agree). Students' answers can range from 9 to 45 in IRO subscale and 11 to 55 in ERO subscale. The Religious Orientation Scale has demonstrated good psychometric properties, with high internal consistency for both subscales (Hill \& Hood, 1999). Hill and Hood (1999) noted that the intrinsic subscale has been found to be more internally consistent than the extrinsic, with $\alpha>.80$ and $\alpha>.70$, respectively.

\section{Data Collection}

The present study was carried out during the class time in the second semester of the academic year (2011). The questionnaires were distributed among the participants by one of the researchers. Participants were given 35 minutes time to answer the questionnaires and there were accompanying instructions. They were informed that the information would be used for research purposes and they were assured that they will be kept completely confidential.

Pearson Product Moment Correlation analysis was used to seek any meaningful relations between the variables locus of control, test anxiety, and religious orientation, and independent sample T-test was used to find any significant differences between males and females regarding these three psychological factors.

\section{Results and Discussion}

The Descriptive Statistics of the variables of the study (LOC, TA, and RO) and students' gender are presented in Tables 1 and 2 respectively.

According to Table 2, the collected data shows that 43 percent out of 100 students were male and 57 percent were female (Table 2).

As can be observed in Table 3, there is a significant negative relationship between ILOC and TA $(P$-value $=.003, \mathrm{r}=-.29)$, and there is a significant positive relationship between ELOC and TA $(P$-value $=.007, \mathrm{r}=.27)$.

According to Table 4, there is a significant positive relationship between ILOC and IRO $(P$-value $=.000, \mathrm{r}=.49)$, and there is a significant positive relationship between ELOC and ERO $(P$-value $=.000, \mathrm{r}=.39)$.

Table 1.

Descriptive Statistics of the variables.

\begin{tabular}{|c|c|c|c|c|c|c|c|}
\hline & $\mathrm{N}$ & Range & Minimum & Maximum & Mean & SD & Variance \\
\hline ILOC & 100 & 10 & 1 & 10 & 6.15 & 2.77 & 7.72 \\
\hline ELOC & 100 & 9 & 11 & 20 & 15.25 & 2.88 & 8.35 \\
\hline TA & 100 & 85 & 60 & 145 & 101.4 & 23.27 & 541.5 \\
\hline IRO & 100 & 39 & 9 & 42 & 28.72 & 13.38 & 178.8 \\
\hline ERO & 100 & 36 & 15 & 51 & 34.07 & 10.56 & 111.6 \\
\hline Valid N & 100 & & & & & & \\
\hline
\end{tabular}

Table 2.

The frequency distribution of the participants' gender.

\begin{tabular}{|c|c|c|c|c|c|}
\hline & & Frequency & Percent & Valid percent & Cumulative percent \\
\hline \multirow[t]{3}{*}{ Valid } & Male & 43 & 43 & 43 & 43 \\
\hline & Female & 57 & 57 & 57 & 100 \\
\hline & Total & 100 & 100 & 100 & \\
\hline
\end{tabular}


Table 3.

Correlations of the variables I-ELOC and TA.

\begin{tabular}{|c|c|c|c|}
\hline & & ILOC & TA \\
\hline \multirow{3}{*}{ ILOC } & Pearson correlation & 1 & $-.29^{* *}$ \\
\hline & Sig. (2-tailed) & - & .003 \\
\hline & $\mathrm{N}$ & 100 & 100 \\
\hline \multirow{4}{*}{ TA } & Pearson correlation & $-.29^{* *}$ & 1 \\
\hline & Sig. (2-tailed) & .003 & - \\
\hline & $\mathrm{N}$ & 100 & 100 \\
\hline & & ELOC & $\mathrm{TA}$ \\
\hline \multirow{3}{*}{ ELOC } & Pearson correlation & 1 & $.27^{* *}$ \\
\hline & Sig. (2-tailed) & 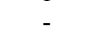 & .007 \\
\hline & $\mathrm{N}$ & 100 & 100 \\
\hline \multirow{3}{*}{ TA } & Pearson correlation & $.27^{* *}$ & 1 \\
\hline & Sig. (2-tailed) & .007 & - \\
\hline & $\mathrm{N}$ & 100 & 100 \\
\hline
\end{tabular}

Note: ${ }^{* *}$ Correlation is significant at the .01 level (2-tailed).

Table 4.

Correlations of the variables I-ELOC and I-E RO.

\begin{tabular}{|c|c|c|c|}
\hline & & ILOC & IRO \\
\hline \multirow{3}{*}{ ILOC } & Pearson correlation & 1 & $.49^{* *}$ \\
\hline & Sig. (2-tailed) & - & 0 \\
\hline & $\mathrm{N}$ & 100 & 100 \\
\hline \multirow{4}{*}{ IRO } & Pearson correlation & $.49^{* *}$ & 1 \\
\hline & Sig. (2-tailed) & 0 & - \\
\hline & $\mathrm{N}$ & 100 & 100 \\
\hline & & ELOC & ERO \\
\hline \multirow{3}{*}{ ELOC } & Pearson correlation & 1 & $.39^{* *}$ \\
\hline & Sig. (2-tailed) & - & 0 \\
\hline & $\mathrm{N}$ & 100 & 100 \\
\hline \multirow{3}{*}{ ERO } & Pearson correlation & $.39^{* *}$ & 1 \\
\hline & Sig. (2-tailed) & 0 & - \\
\hline & $\mathrm{N}$ & 100 & 100 \\
\hline
\end{tabular}

Note: ${ }^{* *}$ Correlation is significant at the .01 level (2-tailed).

As can be observed in Table 5, there is a significant negative relationship between ILOC and TA $(P$-value $=.000, \mathrm{r}=-.80)$, and there is a significant positive relationship between TA and ERO $(P$-value $=.000, r=.59)$.

An Independent Sample T-test was applied to compare the means of locus of control, test anxiety, and religious orientation in two groups of males and females. $P$-Value in all the variables is above the significant level of $\alpha=.05$. So the results indicated that there were no significant differences between two groups of males and females regarding locus of control, test anxiety, and religious orientation (Table 6).

\section{Discussion}

In this section, the research questions presented in this article are dealt with one by one. Each question will be answered based on the findings of the study. Because LOC and RO are bipolar concepts, they will be discussed separately as (I-E LOC and I-E RO) in this section. The first research question asked whether there was any relationship between LOC orientation and TA. The results revealed that there was a significant negative relationship between ILOC and TA. Regarding the negative relationship between ILOC and TA, the finding of this study is in line with Berrenberg's study (1987) who found similar results. However, this finding contrasts with some other studies. For example, Carden et al. (2004) found that internals experienced higher academic procrastination and test anxiety than externals. Regarding the positive relationship between ELOC and TA, the result of this study is in line with some other studies. For example (Archer, 1979; Beekman et al., 2000; Gabbard, Howard, \& Tageson, 1986; Moore, 2006; Watson, 1967) found the same results. However, Carden et al. (2004) found a negative relationship between ELOC and test anxiety.

The second research question asked whether there was any relationship between LOC orientation and RO. The results revealed that there was a significant positive relationship between ILOC and IRO. Strickland and Shaffer (1971), Kahoe (1974), and Sturgeon and Hamley (1979) found the similar results. However, the result of this study contrasts with some other studies. For example McIntosh et al. (1985) found a negative relationship between ILOC and IRO. Also, the results revealed that there was a significant positive relationship between ELOC and ERO. According to Strickland and Shaffer (1971), ERO was positively related to ELOC, specifically controlled by powerful others and chance. However, McIntosh et al. (1985) reported that no significant correlation was found between ELOC and ERO.

The third research question asked whether there was any relationship between RO and TA. The results revealed that there was a significant negative relationship between IRO and TA. The finding of this study support previous established results. For example (Baker \& Gorsuch, 1982; Bergin et al., 1987; 
Table 5.

Correlations of the variables TA and I-ERO.

\begin{tabular}{|c|c|c|c|}
\hline & & TA & IRO \\
\hline \multirow{3}{*}{$\mathrm{TA}$} & Pearson correlation & 1 & $-.80 * *$ \\
\hline & Sig. (2-tailed) & - & 0 \\
\hline & $\mathrm{N}$ & 100 & 100 \\
\hline \multirow{4}{*}{ IRO } & Pearson correlation & $-.80^{* *}$ & 1 \\
\hline & Sig. (2-tailed) & 0 & - \\
\hline & $\mathrm{N}$ & 100 & 100 \\
\hline & & TA & ERO \\
\hline \multirow{3}{*}{$\mathrm{TA}$} & Pearson correlation & 1 & $.59^{* *}$ \\
\hline & Sig. (2-tailed) & - & 0 \\
\hline & $\mathrm{N}$ & 100 & 100 \\
\hline \multirow{3}{*}{ ERO } & Pearson correlation & $.59^{* *}$ & 1 \\
\hline & Sig. (2-tailed) & 0 & - \\
\hline & $\mathrm{N}$ & 100 & 100 \\
\hline
\end{tabular}

Note: ${ }^{* *}$ Correlation is significant at the .01 level (2-tailed).

Table 6.

Gender differences and the variables LOC, TA, and RO.

\begin{tabular}{|c|c|c|c|c|c|c|c|}
\hline & Gender & $\mathrm{N}$ & Mean & SD & Statistics T & $\mathrm{df}$ & $P$-value (sig) \\
\hline \multirow{2}{*}{ ILOC } & Male & 43 & 6.42 & 2.01 & \multirow{2}{*}{-.83} & \multirow{2}{*}{98} & \multirow{2}{*}{.40} \\
\hline & Female & 57 & 5.95 & 3.24 & & & \\
\hline \multirow{2}{*}{ ELOC } & Male & 43 & 15.60 & 3.60 & \multirow{2}{*}{-1.23} & \multirow{2}{*}{98} & \multirow{2}{*}{.21} \\
\hline & Female & 57 & 14.80 & 2.83 & & & \\
\hline \multirow{2}{*}{ TA } & Male & 43 & 99.12 & 23.14 & \multirow{2}{*}{.87} & \multirow{2}{*}{98} & \multirow{2}{*}{.38} \\
\hline & Female & 57 & 103.25 & 23.41 & & & \\
\hline \multirow{2}{*}{ IRO } & Male & 43 & 29.67 & 13.29 & \multirow{2}{*}{.615} & \multirow{2}{*}{98} & \multirow{2}{*}{.54} \\
\hline & Female & 57 & 28.00 & 13.63 & & & \\
\hline \multirow{2}{*}{ ERO } & Male & 43 & 34.21 & 10.73 & \multirow{2}{*}{-.114} & \multirow{2}{*}{98} & \multirow{2}{*}{.91} \\
\hline & Female & 57 & 33.96 & 10.53 & & & \\
\hline
\end{tabular}

Koenig et al., 1988; Maltby et al., 1999; Sturgeon \& Hamley, 1979) found the similar results. However, Maltby and Day (2000) and Watson et al. (2002) did not find any significant relationship between IRO and TA. Also, the results revealed that there was a significant positive relationship between ERO and TA. Baker and Gorsuch (1982), Bergin et al. (1987), Watson et al. (2002) found similar results. However, Maltby and Day (2000) did not find any significant relationship between ERO and TA.

The last research question asked whether there were any differences among males and females regarding ILOC, ELOC, TA, IRO, and ERO. The results revealed that there were not any significant differences among males and females regarding gender.

First, regarding I-ELOC and gender, the results of this study contrast with what McLaughlin and Saccuzzo (1997), and Young and Shorr (1986) found. They reported that females tended to attribute both success and failure outcomes to internal causes significantly more often than males.

Second, regarding test anxiety and gender, there are some studies that are in line with the findings of this study. For example (Fan et al., 1997; Hyde et al., 1990; Pajares \& Graham, 1999) reported that the differences among females and males regarding TA were non-significant and slight. However some other studies by Lashkaripour et al. (2007) and Mousavi et al. (2008) found that TA occurred in girls more than boys.

Third, regarding I-E RO, the findings of this study contrast with some other studies. For instance, according to (Batson et al., 1993; Beit-Hallahmi \& Argyle, 1997; Brown, 1987; Francis, 1997; Paloutzian, 1996; Walter \& Davie, 1998) women are concluded to be more religiously-active than men.

\section{Conclusion}

This study sets out to find out 1) relationship between LOC orientation, TA, and RO among Iranian EFL learners; 2) the effects of gender on LOC orientation, TA, and gender. The findings of this study revealed that there was a significant negative relationship between ILOC and TA, and there was a significant positive relationship between ELOC and TA. Furthermore, there was a significant positive relationship between ILOC and IRO, and there was a significant positive relationship between ELOC and ERO. Finally, there was a significant negative relationship between IRO and TA, and a significant positive relationship between ERO and TA. The variable gender did not prove to have a significant effect on the above-mentioned variables.

\section{REFERENCES}

Abolghasemi, A., Asadi Moghadam, A., Najarian, B., \& Shokrkon, H. (1996). Scale reliability for measurement of test anxiety of Ahwaz's guidance school girls. Journal of Psychological and Educational Sciences of Ahwaz Chamran University, 3, 61-74.

Allport, G. W., \& Ross, J. M. (1967). Personal religious orientation and prejudice. Journal of Personality and Social Psychology, 5, 432-443. 
doi: $10.1037 / \mathrm{h} 0021212$

Archer, R. P. (1979). Relationships between locus of control and anxiety. Journal of Personality Assessment, 43, 617-626. doi:10.1207/s15327752jpa4306_10

Aydin, S., Karakuza, M., \& Elkilik, G. (2009). Teacher effect on the level of test anxiety among young EFL learners. Asian EFL Journal, Teaching Articles, 190-194.

Baker, M., \& Gorsuch, R. (1982). Trait anxiety and intrinsic-extrinsic religiousness. Journal for the Scientific Study of Religion, 21, 119. doi: $10.2307 / 1385497$

Batson, C. D., Schoenrade, P., \& Ventis, W. L. (1993). Religion and the Individual: A social psychological perspective. New York: Oxford University Press

Beekman, A. T. F., de Beurs, E., von Balkom, A. J. L. M., Deeg, D. J. H., van Dyck, R., \& van Tilburh, W. (2000). Anxiety and depression in later life: Co-occurrence and communality of risk factors. American Journal of Psychiatry, 157, 89-95.

Beit-Hallahmi, B., \& Argyle, M. (1997). The psychology of religious behaviour, belief and experience. London: Routledge.

Bergin, A. E., Masters, K. S., \& Richards, P. S. (1987). Religiousness and psychological well-being re-considered: A study of an intrinsiccally religious sample. Journal of Counselling Psychiatry, 34, 197204. doi:10.1037/0022-0167.34.2.197

Berrenberg, J. L. (1987). The belief in Personal control scale: A measure of god mediated and exaggerated control. Journal of Personality Assessment, 51, 194-206. doi:10.1207/s15327752jpa5102_4

Brown, L. B. (1987). The psychology of religious belief. London: Academic Press.

Carden, R., Bryant, C., \& Moss, R. (2004). Locus of control, test anxiety, academic procrastination, and achievement among college students. Psychological Reports, 95, 581-582. doi: $10.2466 / \mathrm{pr} 0.95 .2 .581-582$

Depreeuw, E., \& DeNeve, H. (1992). Test anxiety can harm your health: Some conclusions based on a student typology. In D. G. Forgays, T. Sosnowski, \& K. Wrzesniewski (Eds.), Anxiety: Recent developments in cognitive, psycho physiological, and health research (pp. 211-228). Washington: Hemisphere.

Fan, X., Chen, M., \& Matsumoto, A. (1997). Gender differences in mathematics achievement: Findings from the National Education Longitudinal Study of 1988. The Journal of Experimental Education, 65, 229-242. doi:10.1080/00220973.1997.9943456

Francis, L. J. (1993). Personality and religion among college students in the UK. Personality and Individual Differences, 14, 619-622. doi:10.1016/0191-8869(93)90159-Z

Gabbard, C. E., Howard, G. S., \& Tageson, C. W. (1986). Assessing locus of control with religious populations. Journal of Research in Personality, 20, 292-308. doi:10.1016/0092-6566(86)90136-4

Hembree, R. (1988). Correlates, causes, effects, and treatment of test anxiety. Review of Educational Research, 58, 7-77.

Hyde, J. S., Fennema, E., \& Lamon, S. (1990). Gender differences in mathematics performance: A meta-analysis. Psychological Bulletin, 107, 139-155. doi:10.1037/0033-2909.107.2.139

Kahoe, R. D. (1974). Personality and achievement correlates of intrinsic and extrinsic religious orientations. Journal of Personality and Social Psychology, 29, 812-818. doi:10.1037/h0036222

Koenig, H. G., George, L. K., \& Peterson, B. L. (1998). Religiosity and remission of depression in medically ill older patients. American Journal of Psychiatry, 155, 536-542.

Lashkaripour, K., Bakhshani, N. M., \& Soleymani, M. J. (2007). The relationship between test anxiety and academic achievement in students of guidance school in Zahedan. Zahedan Journal of Research in Medical, 8, 253-259.

Maltby, J., \& Day, L. (2000). Depressive symptoms and religious orientation: Examining the relationship between religiosity and depression within the context of other correlates of depression. Personality and Individual Differences, 28, 383-393. doi:10.1016/S0191-8869(99)00108-7

Maltby, J., Lewis, C. A., \& Day, L. (1999). Religion orientation and psychological wellbeing: The role of the frequency of personal prayer. British Journal of Health, 4, 363-378. doi: $10.1348 / 135910799168704$
McIntosh, D. N., Kojetin, B. A., \& Spilka, B. (1985). Form of personal faith and general and specific locus of control. Annual Meeting of the Rocky Mountains Psychological Association, Tucson, AZ, 24-27 April 1985.

McLaughlin, S. C., \& Saccuzzo, D. P. (1997). Ethnic and gender differences in locus of control in children referred for gifted programs: The effects of vulnerability factors. Journal for the Education of the Gifted, 20, 268-283.

Moore, M. M. (2006). Variation in test anxiety and locus of control in achieving and underachieving gifted and nongifted middle-school students. Doctoral Dissertation, Storrs Mansfield: University of Connecticut.

Mousavi, M., Hghshenas, H., \& Alishahi, M. J. (2008). Effect of gender, school performance, and school type on test anxiety among Iranian adolesecent. Iranian Red Cresent Medical Journal (IRCMJ), 10, 4-7.

Nowicki, S., \& Strickland, B. R. (1973). A locus of control scale for children. Journal of Consulting and Clinical Psychology, 40, 148154. doi: $10.1037 / \mathrm{h} 0033978$

Pajares, F., \& Graham, L. (1999). Self-efficacy, motivation constructs, and mathematics performance of entering middle school students. Contemporary Educational Psychology, 24, 124-139. doi:10.1006/ceps.1998.0991

Putwain, D. W. (2007). Test anxiety in UK schoolchildren: prevalence and demographic patterns. British Journal of Educational Psychology, 77, 579-593. doi:10.1348/000709906X161704

Paloutzian, R. F. (1996). Invitation to the psychology of religion (2nd ed.). Boston, MA: Allyn and Bacon.

Rotter, J. B. (1954). Social learning and clinical psychology. Englewood Cliffs, NJ: Prentice-Hall. doi:10.1037/10788-000

Rotter, J. B. (1966). Generalized expectancies for internal versus external control of reinforcement, Psychology Monographs, 80, 1-28. doi: $10.1037 / \mathrm{h} 0092976$

Rotter, J. B. (1975). Some problems and misconceptions related to the construct of internal versus external control of reinforcement. Journal of Consulting and Clinical Psychology, 43, 56-67. doi: $10.1037 / \mathrm{h} 0076301$

Sarason, I. G. (1975). The Test Anxiety Scale: concept and research. In I. G. Sarason, \& C. D. Spielberger (Eds.), Stress and anxiety (pp. 193-217). Washington DC: Hemisphere.

Sarason, I. G., \& Sarason, B. R. (1990). Test anxiety. In H. Leitenberg (Ed.), Handbookof social and evaluative anxiety (pp. 475-496). New York: Plenum Press.

Spielberger, C. D. (1972). Current trends in theory and research on anxiety. In C. D. Spielberger (Ed.), Anxiety: Current trends in theory and research (pp. 3-9). New York and London: Academic Press.

Strickland, B. R., \& Shaffer, S. (1971). I-E, I-E, \& F. Journal for the Scientific Study of Religion, 10, 366-369. doi:10.2307/1384782

Sturgeon, R. S., \& Hamley, R. W. (1979). Religiosity and anxiety. The Journal of Social Psychology, 108, 137-138. doi:10.1080/00224545.1979.9711977

Vitasari, P., Nubli, A. M., Othman, A., Herrawan, T., \& Sinnadurai, S. K. (2010). The relationship between study anxiety and academic performance among engineering students. Procedia Social and $\mathrm{Be}$ havioral Sciences, 8, 490-497. doi:10.1016/j.sbspro.2010.12.067

Walter, T., \& Davie, G. (1998). The religiosity of women in the modern West. British Journalof Sociology, 49, 640-660. doi: $10.2307 / 591293$

Watson, D. (1967). Relationship between locus of control and anxiety. Journal of Personality and Social Psychology, 6, 91-92. doi: $10.1037 / \mathrm{h} 0024490$

Watson, P. J., Gborbani, N., Davison, H. K., Bing, M. N., Hood Jr., R. W., \& Ghramaleki, A. F. (2002). Negatively reinforcing orientation inner awareness and mental health in Iran and the United States. The International Journal for The psychology of Religion, 12, 255-276. doi:10.1207/S15327582IJPR1204 04

Young, T., \& Shorr, D. N. (1986). Factors affecting locus of control in school children. Genetic, Social, and General Psychology Monographs, 112, 405-417.

Zeidner, M. (1998). Test anxiety, the state of the art. New York: Plenum Press. 